\title{
Parasitic Helminths: A Useful Resource for Inflammatory and Autoimmune Disease Therapy Guofeng Cheng* and Jiaojiao Lin
}

Shanghai Veterinary Research Institute, Chinese Academy of Agricultural Sciences, China

Helminths are multicellular eukaryotic invertebrates with complex life cycles and development. Nematodes (roundworms) and platyhelminths (flatworms) are 2 groups of helminths that colonize the interior of humans. The nematodes include most of intestinal wormsand the filarial worms, whereas the platyhelminths include the flukes, such as the schistosomes, and the tapeworms [1]. Unlike other pathogens such as viruses, bacteria, or protozoa, helminths do not proliferate within their final hosts and the worm burdens in individual hosts depend on the number of initial parasites.

Over the last 40 years, there has been a rapid increase in the incidence of some immune-mediated diseases such as inflammatory bowel diseases (IBD)(e.g., Crohn's disease and ulcerative colitis), asthma, multiple sclerosis and autoimmune (type I) diabetes in industrialized, highly developed countries [2]. However, these diseases are not as common in lessdeveloped countries. The rapid increase in these diseases cannot be explained solely by genetic and/or environmental factors. Interestingly, epidemiology studies indicate that the geographical distribution of these diseases is negatively correlated with helminth-endemic areas $[3,4]$.

Traditionally, parasitism refers to a "hateful" relationship: the parasite benefits at the expense of the health and nutrition of the host for its survival. Indeed, the host could benefit from parasites when colonizing helminths [5]. To some extent, immunological studies theoretically support this notion. Infection with helminth parasites results in a series of immune events that are dominated by $\mathrm{T}$ helper (Th) cell type 2 events [6,7]. Considering the reciprocity in immune regulation where, for example, Th2 cell-derived mediators inhibit the activity of Th1 cells, the hypothesis arises that individuals infected with helminth parasites could be less susceptible to the inflammatory diseases induced by the Th1 response [8]. Therefore, infection with helminths could be used to treat diseases driven by Th1 cells.

Studies on animal models [9-18] indicate that the severity of some immune mediated diseases such as Crohn's disease, colitis, type 1 diabetes, asthma, and arthritis (Table 1) can be alleviated or even blocked upon infection with helminth parasites. These results are encouraging with respect to moving clinical trials toward human patients.

Weinstock's group carried out pioneering studies to investigate the effect of infection with helminth parasites on some inflammatory bowel diseases $[19,20]$. In early clinical trials, they showed that infection with helminths such as Trichuris suis can help prevent or even ameliorate Crohn's disease without significant adverse effects [20]. Then, they commenced a randomized double blind placebo-controlled trial of T. suis in ulcerative colitis patients. This study indicated a significant improvement over that obtained with a placebo in patients receiving the agent $[21,22]$. In these studies, they used T. suis, a kind of pig whipworm, to consider the safety requirements for future medicine development. However, there are concerns that the deleterious effects due to parasite infection on host health may increase the risk of emergence of other infectious disease and of potential host-host transmission.

Consequently, the identification of bioactive molecules in helminth parasites that modulate the immune response of the host may provide an alternative strategy for utilizing parasitic helminths in the treatment of immune mediated diseases. Currently, several molecules such as Ascarissuum PAS1 [23], Dirofilariaimmitis-derived antigen (DiAg) [24] and filarial nematode ES-62 glycoprotein [25] have been shown to be involved in immunomodulation in animal models. An inhibitor

\begin{tabular}{|c|c|c|}
\hline Helminths & Effect of infection or injection & Ref. \\
\hline \multicolumn{3}{|l|}{ Nematode } \\
\hline Ancylostoma caninum & $\begin{array}{l}\text { Inhibition of TNBS-induced colitis in mice } \\
\text { by injecting } A \text {. caninum antigens }\end{array}$ & {$[9]$} \\
\hline Ascaris suum & $\begin{array}{l}\text { Chronic infection reduces eye disease } \\
\text { in mice }\end{array}$ & [10] \\
\hline Trichinella spiralis & Prevention of colitis in C57BL/6 mice & [11] \\
\hline Strongyloides stercoralis & $\begin{array}{l}\text { Suppression of pulmonary allergy in } \\
\text { BALB/c mice }\end{array}$ & [12] \\
\hline \multirow[t]{2}{*}{ Heligmosomoides polygyrus } & $\begin{array}{l}\text { Inhibition of autoimmune type } 1 \text { diabetes } \\
\text { in NOD mice }\end{array}$ & {$[13]$} \\
\hline & Protection from colitis in C57BL/6 & {$[27,28]$} \\
\hline \multicolumn{3}{|l|}{ Platyhelminth } \\
\hline \multirow{5}{*}{ Schistosoma mansoni } & $\begin{array}{l}\text { Inhibition of TNBS-induced colitis in mice } \\
\text { by injecting S. mansoni antigens }\end{array}$ & {$[9]$} \\
\hline & $\begin{array}{l}\text { Inhibition of autoimmune type } 1 \text { diabetes } \\
\text { in NOD mice }\end{array}$ & [13] \\
\hline & $\begin{array}{l}\text { Inhibition of type } 1 \text { diabetes in NOD mice } \\
\text { by injecting S. mansoni antigens }\end{array}$ & {$[14]$} \\
\hline & $\begin{array}{l}\text { Prevention of DSS-induced colitis in } \\
\text { BALB/c mice }\end{array}$ & [15] \\
\hline & $\begin{array}{l}\text { Suppression of collagen-induced arthritis } \\
\text { in mice }\end{array}$ & {$[16]$} \\
\hline \multirow[t]{2}{*}{ Schistosoma japonicum } & $\begin{array}{l}\text { Inhibition of asthma development } \\
\text { in BALB/c mice by injecting the egg } \\
\text { antigens }\end{array}$ & {$[17]$} \\
\hline & $\begin{array}{l}\text { Protective effects for arthritis in DBA } / 1 \\
\text { mice }\end{array}$ & [18] \\
\hline
\end{tabular}

DSS, dextran sodium sulphate; NOD, Non-obese diabetic; DNBS, dinitrobenzene sulfonic acid; TNBS, trinitrobenzene sulfonic acid

Table 1: Examples of helminth parasites in animal models for inflammatory and autoimmune disease therapy.

*Corresponding author: Guofeng Cheng, Shanghai Veterinary Research Institute, Chinese Academy of Agricultural Sciences, Key Laboratory of Animal Parasitology, Ministry of Agriculture, China, Tel: 86-213-429-3659; Fax: 86-215408-1818; E-mail: cheng_guofeng@yahoo.com

Received June 27, 2013; Accepted August 17, 2013; Published August 20, 2013

Citation: Cheng G, Lin J (2013) Parasitic Helminths: A Useful Resource for Inflammatory and Autoimmune Disease Therapy. J Bioanal Biomed 5: 075-076. doi:10.4172/1948-593X.1000084

Copyright: $\odot 2013$ Cheng G, et al. This is an open-access article distributed under the terms of the Creative Commons Attribution License, which permits unrestricted use, distribution, and reproduction in any medium, provided the original author and source are credited. 
Citation: Cheng G, Lin J (2013) Parasitic Helminths: A Useful Resource for Inflammatory and Autoimmune Disease Therapy. J Bioanal Biomed 5: 075-076. doi:10.4172/1948-593X.1000084

of the apoptosis protein from Schistosoma japonicum (SjIAP) was also cloned and molecularly characterized by our group, and the results indicated that SjIAP can inhibit caspase activity and caspase 3 expression in human $293 \mathrm{~T}$ cells. Although the involvement of SjIAP in immunomodulation in the host remains to be determined, our preliminary study suggests that SjIAP could bea potential agent for treating liver injury, organ transplantation, and other diseases by inhibiting cellular apoptosis [26-28].

Parasitic helminths are a useful resource for inflammatory and autoimmune disease therapy. A deep understanding of the mechanisms of parasite infection and host immune response and of the molecular bases of these mechanisms is critical for developing therapeutic strategies for inflammatory and autoimmune diseases. The utilization of new "-omics" techniques such as secretomics, immunomics and metabolomics need to be accelerated to tap resources that can then be more beneficial for human beings.

\section{Acknowledgements}

The study was funded by the National Natural Science Foundation of China (Grant No. 30901068), Science and Technology Commission of Shanghai Municipality of China (Grant No.10410703400 and Grant No.10PJ1412300), and Shanghai Talent Developing Foundation of China (Grant No.2009032).

\section{References}

1. Hotez PJ, Brindley PJ, Bethony JM, King CH, Pearce EJ, et al. (2008) Helminth infections: the great neglected tropical diseases. J Clin Invest 4: 1311-1321.

2. von Mutius E (2007) Allergies, infections and the hygiene hypothesis--the epidemiological evidence. Immunobiology 6:433-439.http://www.ncbi.nlm.nih. gov/pubmed/17544828

3. Weinstock JV, Summers RW, Elliott DE, Qadir K, Urban JF Jr, et al. (2002) The possible link between de-worming and the emergence of immunological disease. J Lab Clin Med 6: 334-338

4. McKay DM (2006) The beneficial helminth parasite? Parasitology 1: 1-12.

5. Desowitz M, Haramonious parasite (1981) New Guinea Tapeworms and Jewish Grandmothers. Pickwick Press. 179-205.

6. Maizels RM (2009) Exploring the immunology of parasitism--from surface antigens to the hygiene hypothesis. Parasitology 12: 1549-1564.

7. McKay DM (2009) The therapeutic helminth? Trends in Parasitology 3: 109114

8. Matisz CE, McDougall JJ, Sharkey KAMcKay DM (2011) Helminth parasites and the modulation of joint inflammation. Journal of Parasitology Research.

9. Ruyssers NE, De Winter BY, De Man JG, Loukas A, Pearson MS, et al. (2009) Therapeutic potential of helminth soluble proteins in TNBS-induced colitis in mice. Inflamm Bowel Dis 4: 491-500.

10. Schopf L, Luccioli S, Bundoc V, Justice P, Chan CC, et al. (2005) Differential modulation of allergic eye disease by chronic and acute ascaris infection. Invest Ophthalmol Vis Sci 8: 2772-2780.

11. Khan WI, Blennerhasset PA, Varghese AK, Chowdhury SK, Omsted P, et al (2002) Intestinal nematode infection ameliorates experimental colitis in mice. Infect Immun 11: 5931-5937.

12. Wang CC, Nolan TJ, Schad GA, Abraham D (2001) Infection of mice with the helminth Strongyloides stercoralis suppresses pulmonary allergic responses to ovalbumin. Clin Exp Allergy 3: 495-503.

13. Saunders KA, Raine T, Cooke A, Lawrence CE (2006) Inhibition of autoimmune type 1 diabetes by gastrointestinal helminth infection. Infection and Immunity 1 : 397-407.

14. Zaccone P, Fehervari Z, Jones FM, Sidobre S, Kronenberg M, et al. (2003) Schistosoma mansoni antigens modulate the activity of the innate immune response and prevent onset of type 1 diabetes. Eur J Immunol 5: 1439-1449.

15. Smith P, Mangan NE, Walsh CM, Fallon RE, McKenzie AN, et al. (2007) Infection with a helminth parasite prevents experimental colitis via a macrophage-mediated mechanism. J Immunol 7: 4557-4566.

16. Osada Y, Shimizu S, Kumagai T, Yamada S, Kanazawa T (2009) Schistosoma mansoni infection reduces severity of collagen-induced arthritis via downregulation of pro-inflammatory mediators. Int J Parasitol 4: v457-464.

17. Yang J, Zhao J, Yang Y, Zhang L, Yang X, et al. (2007) Schistosoma japonicum egg antigens stimulate CD4 CD25 T cells and modulate airway inflammation in a murine model of asthma. Immunology 1: 8-18.

18. He Y, Li J, Zhuang W, Yin L, Chen C, et al. (2010) The inhibitory effect against collagen-induced arthritis by Schistosoma japonicum infection is infection stage-dependent. BMC Immunol 11: 28.

19. Summers RW, Elliott DE, Qadir K, Urban JF Jr, Thompson R, et al. (2003) Trichuris suis seems to be safe and possibly effective in the treatment of inflammatory bowel disease. Am J Gastroenterol 9: 2034-2041.

20. Summers RW, Elliott DE, Urban JF Jr, Thompson R, Weinstock JV (2005) Trichuris suis therapy in Crohn's disease. Gut 1: 87-90.

21. Summers RW, Elliott DE, Urban JF Jr, Thompson RA, Weinstock JV (2005) Trichuris suis therapy for active ulcerative colitis: a randomized controlled trial. Gastroenterology 4: 825-832.

22. Summers RW, Elliott DE, Weinstock JV (2005) Is there a role for helminths in the therapy of inflammatory bowel disease? Nat Clin Pract Gastroentero Hepatol 2: 62-63.

23. Oshiro TM, Enobe CS, Araujo CA, Macedo MS, Macedo-Soares MF (2006) PAS-1, a protein affinity purified from Ascaris suum worms, maintains the ability to modulate the immune response to a bystander antigen. Immunol Cell Biol 2: $138-144$.

24. Imai S, Fujita K (2004) Molecules of parasites as immunomodulatory drugs Curr Top Med Chem 5: 539-552.

25. McInnes IB, Leung BP, Harnett M, Gracie JA, Liew FY, et al. (2003) A novel therapeutic approach targeting articular inflammation using the filarial nematode-derived phosphorylcholine-containing glycoprotein ES-62. J Immunol 4: 2127-2133.

26. Peng J, Yang Y, Feng X, Cheng G, Lin J (2010) Molecular characterizations of an inhibitor of apoptosis from Schistosoma japonicum. Parasitol Res 4: 967976.

27. Hang L, Setiawan T, Blum AM, Urban J, Stoyanoff K, et al. (2010) Heligmosomoides polygyrus infection can inhibit colitis through direct interaction with innate immunity. J Immunol 6: 3184-3189.

28. Blum AM, Hang L, Setiawan T, Urban JP Jr., Stoyanoff KM, et al. (2012) Heligmosomoides polygyrus bakeri induces tolerogenic dendritic cells that block colitis and prevent antigen-specific gut T cell responses.J Immunol 5 : 2512-2220. 